\title{
ENSURING RIGHTS OF WOMEN WITH DISABILITIES (WWD) IN BANGLADESH: LAWS AND CONCERNS
}

\author{
Akter, K.K \\ School of Social science, Humanities and Language (SSHL), Bangladesh Open University
}

\begin{abstract}
People with disabilities are in most cases treated as subject of donations and social welfare. In Bangladesh, though approximately 15 million people suffer from various disabilities and a large portion of population of Bangladesh comprises of women with disabilities (WWD) living in an environment and society dominated by male. They are been discriminated against, socially marginalized and do not have access to basic social services. Moreover they are been victims of different crimes including domestic violence, rape or dowry which inflicts them severe loss and sufferings. Considering this situation, this article firstly aims to find out the status of WWD under human rights perspective considering major national and international instruments. Then it tries to review the ambit of legal protection of the women disabled persons in Bangladesh along with its major defaults. Lastly it recommends how the rights of WWD can fully be warranted in reference to best practices followed by other progressive states.
\end{abstract}

Keywords: Women with disabilities, rights, legal protection, reforms

\section{INTRODUCTION}

The rights of women with disabilities (WWD) are one of most ignored issues in Bangladesh. Women with disabilities are deprived of rights and privileges because of the existing social attitude towards them. Though in Bangladesh, approximately 15 million people suffer from various disabilities. (Haider 2015) but still it is regrettable that such huge population is suffering each and every day due to improper care and treatment. In Bangladesh a large number of disabled populations including women with disability have limited access to education and employment. In the families, they do not participate in the decision making process even in social gatherings (Women Watch n.d.). They have movements outside their homes with assistance from family members as and when needed. Moreover, they have limited awareness about policies and legal provisions on disability rights which makes the situation far worst. Considering this situation, this article firstly aims to find out the status of WWD under human rights paradigm considering major international instruments on

Corresponding Author Email: urmee.kohinur@gmail.com women. Then it tries to explore the ambit of legal protection of the disabled women in Bangladesh along with its failures. Lastly it recommends how the rights of

WWD can be fully realized in reference to best practices followed by other states.

The research study is basically based on primary and secondary sources. It is primarily based on a systematic literature review of the existing legal materials on disability rights in context of Bangladesh. Moreover three specific legal documents on disability rights have been selected to analyze for intensifying the issues. They are the Convention on the Rights of Person with Disability, Protection of the Rights of the Persons with Disabilities Act 2013 and the People with Disabilities (equal opportunities, protection of rights and full participation) Act, 1995. However, in order to determine the practical factors and impacts, five case studies and several numbers of semi-structured interviews of the relevant persons working and dealing with the issue are conducted as well. The selection of people who are interviewed and chosen as case-study for this study 
is done by way of purposive sampling technique. Semi-structured interviews with open-ended questions are conducted with key respondents having academic and managerial expertise on disability rights.

\section{Defining Women with Disability}

The term 'disability' means the lack of competent physical and mental faculties; the absence of capability to perform an act. It usually signifies incapacity to exercise all the legal rights ordinarily possessed by an average person (Free Dictionary n.d.). It is an umbrella term covering impairments, activity limitations, and participation restrictions. In connection to that impairment means having problem in body function or structure; an activity limitation is a difficulty encountered by an individual in executing a task or action; while a participation restriction is a problem experienced by an individual in involvement in life situations. Thus, disability is a complex phenomenon, reflecting an interaction between features of a person's body and features of the society in which he or she lives (WHO, 2013). Generally person suffering from the following forms of disorders are considered as disabled: autism or autism spectrum disorders, physical disability, mental illness leading to disability, visual infirmity, speech impairment, intellectual disability, hearing infirmity, deafblindness, cerebral palsy, down syndrome, multiple disability, and other disabilities.

Lately in the Protection of the Rights of the Persons with Disabilities Act 2013, the term refers to any person having permanent physical, emotional, intellectual, developmental or sensual incapacity and due to what he or she cannot take part actively in the society or his/her social participation been interrupted is considered as disable person (Protection of the Rights of the Persons with Disabilities Act 2013, s 2). Moreover the Act mentioned different types of disabilities including signs and symptoms i.e. Autism, Physical, Psychosocial, Visual Impaired, Speech Disability, Intellectual Disability, Hearing Disability, HearingVisual Disability, Cerebral Palsy, Down Syndrome, Multiple Disabilities (Protection of the Rights of the Persons with Disabilities Act 2013, s 3).
Though it is evident that the Disability Act includes a wider ambit while defining the term 'disability' but there are some extents to refine it. As example 'disability by injury' has not included herein.

\section{Rights of Women with Disability (WWD) and State Obligations under International Human Rights Instruments}

There are also various international instruments regarding protection of the rights of the disabled women, such as Convention on the Rights of Persons with Disabilities, Optional Protocol to the Convention on the Rights of Persons with Disabilities 2006 etc.

But particularly on women the Convention on the Elimination of Discrimination against Women (CEDAW), 1979 states that discrimination against women violates the principles of equality of rights and respect for human dignity which is an obstacle to the participation of women, on equal terms with men, in the political, social, economic, and cultural life (CEDAW, Preamble). The Convention is also concerned that women in poverty have the least access to food, health, education, training, and opportunities for employment and other needs. It provides a definition of discrimination against women and imposes obligation to States Parties to embody the principle of equality of men and women in their national constitutions or other appropriate legislation and to adopt appropriate legislative and other measures, including sanctions where appropriate, prohibiting all discrimination against women (CEDAW, Article-2).

Next, the International Covenant on Civil and Political Rights, 1966 specifically guarantees certain rights to women, lists a broad spectrum of rights to be applied equally to men and women, and prohibits all discrimination based on sex. The rights found in the Covenant are to be recognized without distinction of any kind, such as sex or other status (ICCPR, Article-2). The term 'other status' also may apply to persons with disabilities.

Further, the International Covenant on Economic, Social and Cultural Rights (ICESCR) 1966 requires member States to comply with the rights under the Covenant to be exercised without discrimination of any kind as to race, color, sex, language, religion, 
political or other opinion, national or other (Article-2). It states that the Parties to ensure the equal right of men and women to the enjoyment of rights (Article-3) and equal remuneration for work of equal value (Article-7).

The Declaration on the Elimination of Violence Against Women urges to protect some groups of women, such as women belonging to minority groups, indigenous women, refugee women, migrant women, women living in rural or remote communities, destitute women, women in institutions or in detention, female children, women with disabilities, elderly women and women in situations of armed conflict, are especially vulnerable to violence (DEVAW, Preamble).

The Beijing Declaration focuses on preventing and eliminating all forms of violence against women and girls. It provides that Parties shall take efforts to ensure equal enjoyment of all human rights and fundamental freedoms for all women and girls who face multiple barriers to their empowerment and advancement because of factors such as disability (Article-32).

The Vienna Declaration and Program of Action emphasizes that human rights are universal, indivisible and independent. Paragraph 18 provides for the elimination of gender-based violence and all forms of sexual harassment and exploitation. In addition, it calls for the eradication of all forms of discrimination on grounds of sex (Paragraph 5).

Being the main instrument on disability rights the Convention on the Rights of Persons with Disabilities imposes general obligations (Article-4, CPRD) to the party states which are mentioned that States Parties undertake to ensure and promote the full realization of all human rights and fundamental freedoms for all persons with disabilities without discrimination of any kind on the basis of disability.

1. Rights of WWD and state obligation under this convention are mentioned below:

2. Equal protection and equal benefit of the law. (Article-5) and Right to full and equal enjoyment of all human rights and fundamental freedoms by disable women and girl (Article-6).

3. Right to full enjoyment by children with disabilities of all human rights and fundamental freedoms on an equal basis (Article-7).

4. Right to access the physical environment, to transportation, to information and communication (Article-9).

5. Right to life and effective enjoyment by persons with disabilities on an equal basis with others and to get equal recognition before law (Article10 and 12).

6. Right of protection and safety in situations of risk, including situations of armed conflict, humanitarian emergencies and the occurrence of natural disasters (Article-11).

7. Access to justice for persons with disabilities (Article-13).

8. Enjoyment of the right to liberty and security of person and right to have respect for his integrity on equal basis (Article-14 and 17).

9. Right to be protected from all forms of exploitation, violence and abuse, including their gender-based aspects (Article-16).

10. Right of movement, to freedom to choose their residence and to a nationality (Article-18).

11. Full inclusion and participation in the community (Article-19).

12. Right to freedom of expression and opinion (Article-21).

13. Right to privacy of personal, health and rehabilitation information (Article22).

14. No discrimination in all matters relating to marriage, family, parenthood and relationships, on an equal basis (Article-23).

15. Right to education (Article-24).

16. Right to health (Article-25).

17. Right to attain and maintain independence (Article-26).

18. Right to work (Article-27). 
19. Right of adequate standard of living and social security (Article-28).

20. Right of participation in political and public life, and in cultural life, recreation, leisure and sport (Article30).

The list of rights includes rights of civil, political, social, economic and cultural in nature. Considering the convention as a benchmark now it is to examine that how the legal diagram of Bangladesh has included them in favor of disable women.

But before entering to the legal discussion, as a situational analysis of Bangladesh, certain casestudies are been discussed hereunder.

\section{Case-Studies}

\section{Case 1}

Nilamoni is a disabled girl child aged of 12 years lives in a small village of Jamalpur district. Her mother had a tough time while giving her birth. Her mother was not taken to the hospital as it is the tradition of her family to give birth in the home with the help of local women. In time of Nilamoni's birth due to some complicacy, she was hurt but nobody realized that it would turn into a permanent disability. From the age of 3 it was found that she is incapable of walking and communicating with others. She was taken to medical professionals at the age of five but the doctor said that due to brain injury caused in time of birth, she is incapable to walk and hear-talk. Her parents are now helpless because there is no specialized medical facility and special school in nearby areas. Moreover due to social stigma, her movement has been restraint. Only she is getting tk.400 (USD 5) per month from the Ministry of Social Welfare as allowance.

\section{Case 2}

Ratna Begum is a woman of 20 years. She worked in a garments industry near Savar district. In 2012 an accident occurred in the factory and while rushing towards basement she was injured and lost her right leg and her job. From then she moves with her wheelchair and became burden to her family. She got a minimum amount as compensation from the employer. She claimed that she can work like other workers if she gets back the job because she worked with hands in the swing department. But the employers rejected her saying that there is no lift in the building so she won't be able to reach to her compartment.

\section{Case 3}

Jahanara Khatun lives in Shirajganj aged of 25 year. She was the fourth girl child of the family and was unwelcomed as her father wanted a male child. She is an autistic person and from the very beginning of her childhood, she was treated as a burden of the family. She was not allowed to come before guests or to room outside the house. She got sick several times and found that she suffered for malnutrition for a long time. Sometimes she gets assaulted by her family members for causing disturbances. She suffers from diseases time to time and remains untreated. She did not get a chance to admit in school or to have any employment opportunity. That's how her life is going on with distress and humiliation.

\section{Case 4}

$\mathrm{X}$ (unwilling to expose name) a women of 32 years lives in a slum of Dhaka city. Her home village is in Bhola, Barisal district. She is deaf-mute from her birth but otherwise physically fit enough to continue with her life. She was born in a povertystriken family and had no chance to admit in school because of her disability. At the age of 19 she was raped by her cousin but nothing happened to the wrong-doer because nobody believed her. She was unable to communicate and explain the incident to the police. At the age of 22 she got married to a local small businessman who claimed dowry later on. Her husband physically assaulted her and pressurized her to bring money from her father. As she failed to do so, he divorced her. She came to Dhaka after that and now working in houses as domestic help.

\section{Case 5}

Shopna Akter is a women of 47 years. She works in a NGO in Dhaka. At the age of 31 she had a road accident and lost her legs. From then she moves with her wheelchair. Though she is a graduate and efficient in her professional work, she faces obstacle in everyday life. It is hard for her to enter 
in establishments like even hospitals or to get transport. She has to change her house and re-settle near her office because it was impossible for her to live remote areas. She is working for almost 15 years but still sometimes she gets low treatment from her male colleagues. Sometimes she felt that she has been treated as a disable person which makes her unhappy. Moreover in her personal life, she is unmarried and lives with her parents. After her father's death, she got minimum share of her father's property disobeying the rules of inheritance.

Now considering the reality-check, it can be examined that why and how the legal protection is insufficient or feasible for those women. Before that some co-relating elements that negatively affecting disability rights of women are discussed herein under.

\section{WWD and Co-Relating Elements Prevailing in Bangladesh}

\section{Lack of health-care during childhood}

Lack of health care during childhood of a girl child is one the main reasons for permanent disability. Several national and international agencies conduct situational analysis of children with disabilities with a view to their organizational mandates. Studies by Sightsavers International found that 4.6 million children suffer from blindness. 29.25 percent deaf children worldwide suffer from hearing and speech problem and 19.8 percent are in the age group of $15+$. According to Shishu Bikash Kendra, 27.6 percent suffer from cerebral palsy and intellectual disability is in the range of 15.1 percent (DARA, 2012). The report of UNICEF in 2010 indicates that the main causes of disability are low access to health and disability services. When appropriate health services are absent, persons' impairments lead to permanent disability.

\section{Gender discrimination and violence against WWD}

Discrimination is often compounded for women on the grounds of gender, age and minority status. Gender related violence is a cause and consequence of disability. Gender related practices such as son preference, abandonment of the girl child, discriminatory feeding practices, child marriage, dowry are all gender related acts of violence that lead to mental, physical and psycho social disability. Further, Rape or sexual harassments are probably the most common forms of violence against disabled women in Bangladesh. A disabled woman who is victim of violence undergoes two crises, one the violence and other the subsequent investigation and trial or legal complexity (CRPBangladesh, 2015). Moreover physical assault by family members or violence by intimate partner is often not considered as a crime rather a day-to-day incident. Among the women interviewed in a survey, about $84 \%$ reported ever having experienced at least one act of emotional abuse, physical, or sexual violence from their partner during their lifetime (Hasan \& Muhaddes, \& Selim \&Rashid, 2014).

\section{Poverty and social stigma}

It is found that more than $50 \%$ of the impairments in Bangladesh that result in people being included in current disability prevalence rates are preventable and directly associated to underdevelopment i.e., poverty. People with inadequate resources tend to have lower awareness and consideration of disability and access to basic health care services which lead to a greater risk of increasing impairment (CDD-Bangladesh, 2014). Poverty also reinforces negative attitudes towards persons with disabilities, acting as a barrier to insertion and service delivery and transforming impairments into disabilities. Moreover social stigma prevails at a high level as it is said that having a disable child is like a curse.

\section{Less opportunities ensured and implemented}

Socio-economic opportunity provided to disable women must be ensured and monitored by the concerned authority. As we find that through laws, policies and ministerial rules some changes are been introduced but in reality those are not monitored well. As example it is found that 5\%seat of transportation (Protection of the Rights of the Persons with Disabilities Act, 2013, s 32) should be kept for disable person but it is not been executed. Moreover, the law ensures active participation of disable person in development activities but in fact, it remains an unreal promise. 


\section{Existing Legal Framework for Disabled Women in Bangladesh}

The constitution of Bangladesh (Articles 10, 11, $15,17,19,20,21,27,28,29,31,32,36)$ ensures equal rights and the government of Bangladesh is bound to protect the rights and dignity of all citizens equally and without any discrimination. In connection to that in 2001 the Disability Welfare Act (Act no. 12) was passed. Later in 2007, Bangladesh ratified UN convention on the rights of persons with disability (UNCPRD) (Wikipedia, 2014). Considering it, state parties are under obligation to incorporate affirmative actions in their disability policies so that through some positive interventions equal participation and opportunity can be ensured (Faruque, 2012). In 2013 Protection of the Rights of the Persons with Disabilities Act has been passed and enforced.

This Act has been passed with a view to ensuring the rights and dignity of persons with disabilities. The newly enacted law will abolish the former "Bangladesh Persons with Disability Welfare Act, 2001." The aim of the act is to guarantee the educational, physical and mental improvement of disabled persons and to support their participation in social and state activities by removing all sorts of discrimination. Lastly in 2015 the Rights and Protection of Persons with Disability Rules has been notified in November.

\section{Aspects of the Act Along with Major Loopholes}

The law stipulated certain rights for the disabled persons (Section-16). According to the newly enacted law, another 19-member national executive committee (Section-17) headed by the social welfare secretary, will work for national implementation of the law, and ensures some the following rights:

- To survive and grow in full with legal recognition in every sphere of life, and access to justice

- Right to inheritance, Freedom of expression and opinion, and access to information

- To live in a society with parents, legitimate or legal guardian and children, and to have marital relations and to form families

- To attend every level of education and educational institutions - either special or integrated

- To get a safe and healthy environment and protection from persecution

- Subject to availability, the highest quality of health services

- To have congenial environment for the convenience and reasonable accommodation in all areas including education and work

- To get appropriate service and rehabilitation to attain physical, mental and technical capacity in order to fully integrate in all aspects of the society

- To obtain safe housing and rehabilitation, as far as possible, for individuals with disabilities who are dependent on the parents and subsequently isolated from parents

- To participate in culture, entertainment, tourism, leisure and sporting activities

- According to the desire of hearingimpaired and speech-impaired persons, Bengali sign language to be accepted as the first language

- To receive national identity cards, inclusion in the list of voters, to give vote and to participate in elections and any other rights prescribed by the government by notification in the official gazette

It has been appreciated by all that the act acknowledges certain rights of PWD whereas the previous act only dealt with provisions under the title of "welfare". So the shift from 'welfare' to 'rights and protection' itself admits the truth of existence and justification of disability rights. Though it is considered as a right-based law still there are some ambiguities or insufficiencies need to be addressed. From the document analysis, casestudies and semi-structured interviews the major loopholes are found been mentioned below. 


\section{Process of Identification}

In the act it is said that for the purpose of identification and registration the disable person himself or any other person from his behalf must apply (Protection of the Rights of the Persons with Disabilities Act, 2013,s 31) which does not comply with the socio-economic situation of Bangladesh. As it is observed that in India that the state government takes the responsibility to identify by screening all children at least once in a year to identify "at -risk" cases. [People with Disabilities (equal opportunities, protection of rights and full participation) Act, 1995, s.25] So early detection of disabilities should insert in the act which to be done by medical board and 'disability certificate' should be issued (at the time of birth and early stages of childhood) for future legal privileges. When interviewed on $10^{\text {th }}$ December $2015 \mathrm{Mr}$. Talukder Rifat Pasha, Assistant Project officer, Work for a Better Bangladesh (WBB Trust), he also alleged that after examining some other provisions it seems that there is a tendency in the act to confer liabilities to the families or organizations of the disabled persons rather taking responsibilities on the shoulder of the concerned authority.

\section{Absence of Comprehensive Education Scheme}

Referring to education, in section 33 it is only mentioned that no discrimination will be spared in admission in educational institutions but no specific provision is found referring free education in normal school upon 18 years or likewise. Moreover conducting special part-time classes, providing free of cost special books and equipments, providing educational institutions teaching aid, special teaching materials are not been incorporated. When interviewed on $10^{\text {th }}$ December 2015 Mr. Atiqur Rahman, Project officer, Work for a Better Bangladesh (WBB Trust), he added that no provision is found on comprehensive education scheme for disable a woman which is a major loophole of the Act. It may be said in defense that the ministry of social welfare is conducting projects and programs for such purpose but it is undoubted that a disabledfriendly state must provide full outline to execute disability rights in their legislations to give it a legal mandate.

\section{Addressing Employment Rights}

To add another point, employment opportunity in the Act got place ensuring non-discrimination on the ground of disability but no specific and special schemes are found. In India the act ensures the responsibility of the government to identify posts that can be reserved for PWD. [People with Disabilities (equal opportunities, protection of rights and full participation) Act, 1995, s.29] It tries to ensure appointment of $3 \%$ of vacancies to be filled by them. Further, special employment exchange programs are been introduced to enhance such opportunities. When interviewed on 4th January 2016 Ms.Sabrina Sultana, President and Founder, Bangladesh Society for the Change and Advocacy Nexus (B-SCAN) explained the importance of inserting those provisions along with strategies like access to small credit or negotiation with employers to include disable women in industries for their economic independence. She also added that according to the Labor law of Bangladesh provisions are there to provide compensation for injury caused to employee in course of employment which is insufficient. But it would be better if the employer keeps the labor in the employment and sifts her to any other division of work she is capable of doing.

No provision of participation of WWD as representative

Certain committee's i.e. national co-ordination committees, city committees have been formed under the Act which are responsible to ensure disability rights but it is major mistake that no position for a representative from disabled women is found. It is a general principle of public law that in case of enforcement of rights, representatives must be appointed who can take part in the legal process. When interviewed on $12^{\text {th }}$ January 2016 Dr.Shah Alam, Member, Bangladesh Law Commission he also mentioned that this provision should be amended and reformed to ensure participation of WWD in the concerned committees.

\section{Insertion of Less Affirmative Actions}

In the act, a few affirmative actions are mentioned whereas there should be a list of such act ions. As 
example, for the preferential allotment of land to establish houses, special schools, special recreational centers, research centers or factories are essential for each defined territory. When interviewed on $9^{\text {th }}$ January $2016 \mathrm{Mr}$. Iftekhar Mahmud, Vice President, Society for Unique Capable Citizens (SUCC) has also confirmed that without logistic support and access to those support, it would be hard for disable person including women to flourish.

\section{Absence of Emergency Safety Provisions}

Most importantly assessments of risk situation and humanitarian emergencies have been absent which is surely a major gap. All necessary measures to ensure the protection and safety of persons with disabilities in situations of risk, including situations of armed conflict, humanitarian emergencies and the occurrence of natural disasters not addressed by the Act.

\section{No Special Attention to Law Reforms for Disable Women}

The Act does not protect WWD from all forms of exploitation, violence and abuse, including their gender-based aspect which is another imperative under the Convention (Article-16). Provisions protecting the rights of women with disabilities must be included in the Dowry Prohibition Act 1980, Domestic Violence Act, Family Court Ordinance 1984, draft Victim Witness Protections Laws and other pending law reform initiatives. When interviewed on $12^{\text {th }}$ January 2016 Dr. Shah Alam, Member, Bangladesh Law Commission mentioned that the new witness protection protocol will be beneficial in the case of witnesses for blind (and hearing impaired) victims of rape, abuse and violence. It is obviously a good sign of change. Moreover in cases of violence, exploitation and torture on disabled women, legal provisions related to summons of persons, trial in absentia, adjournment and appeals (Sections in Chapter VI, Section 339 B, Section 344 and Sections contained in the Code of Criminal Procedure (Cr.P.C.) should be strictly complied with (BLAST, 2014).

\section{No directory provisions for making future laws and policies relating to women}

There are certain government policies regulated by Ministry of women and children along with ministry of social welfare. In the Act, it was expected that some directory provisions will be there that can be used as guidelines while making relevant laws. As example in courts, no sign language is used which should be, so while making any change relating to court proceedings the convenience of WWD should be in consideration.

It is noteworthy that those shortcomings are affecting the enforcement of disability rights of PWD because it is not only the aim of a law to recognize substantive rights but to provide full process of effective execution and implementation. Moreover considering the three basic doctrines of disability rights (empowerment, participation and legal protection) it is found that the act has been admitted those but in a limited capacity which needs further reform.

\section{CONCLUSION ALONG WITH RECOMMENDATIONS}

WWD are the most vulnerable and disadvantage segment of the society and they have faced and continue to struggle against many social and economic disadvantage (The Danish Bilharziasis Laboratory, 2004). In Bangladesh, WWD face hardships and sufferings due to lack of proper declaration of their special requirements within a proper legal framework. In such background the paper has tried to discuss on the legal propositions relating to disability rights. The objective of the paper was to find out the legal lacunas of disability laws of Bangladesh with comparing international legal instruments and laws of progressive states.

With the above discussions I draw conclusion with recommendations as follows:-

- Necessary amendments should be done in the Act, 2013 and to insert most essential provisions for WWD like emergency safety provision and detail list of affirmative actions.

- Identify and modify contradictory laws and policies necessary to protect rights of WWD and to prevent violence against them.

- Participation of WWD or representatives of them must be ensured in the 
committees because they deserve positions to ensure their special treatment.

- Insertion of provision that can direct law-makers while enacting disable women friendly public and private laws must be inserted in the Act.

- Judicious mind should be expanded particularly by courts in terms of ensuring substantive and procedural equality. Moreover, in the justice sector disability issues should be incorporated in the training module for the police, court and prison officials and in the Bar Council's 'Canons of Professional Conduct and Etiquette' for practicing lawyers.

So, disability laws should be improved to include women with disabilities within mainstream development efforts by ensuring their needs. Strategies must emphasize on the importance of simultaneously removing other barriers to inclusion such as negative misperceptions of disability, lack of physical convenience, difficulties in communicating and the low level of skill, selfreliance and leadership competence of women with disabilities themselves.

\section{ACKNOWLEDGEMENT}

To examine the ambit of legal protection of WWD and prepare this research article I have relied on primary and secondary sources. I am grateful to a number of people in conducting the research as they helped me in many ways. Firstly I would like to express my sincere gratitude to Barrister Tapas Kanti Baul who inspired me to work on disability rights. In a previous article I worked on disability laws of Bangladesh but in this article I added the gender dimension and magnified the issue. I am also highly indebted to Mr. Iftekhar Mahmud, Ms. Sabrina Sultana and Dr. Shah Alam for their kind and cordial support.

\section{REFERENCES}

Bangladesh Legal Aid \& Services Trust (BLAST), 2014, Making Justice Accessible: Women with Disabilities and the Right of Access to Justice in Bangladesh, Date of Access: 2/01/2016,
http://www.blast.org.bd/content/news/WWD-Paragraphfor-8-March.pdf

Center for disability in development, 2014, Disability Information,

Date of Access: 3/12/2015.

$<$ http://www.cdd.org.bd/about-disability/disabilityinformation>

Convention on the Rights of Persons with Disabilities

Convention on the Elimination of Discrimination against Women (CEDAW), 1979

Disability Welfare Act, 2001

Declaration on the Elimination of Violence against Women

Faruque ,A 2012, Critically disadvantaged people and affirmative action: A Bangladesh context, Dr. Abdullah Al faruque, Human rights and critically disadvantaged people, ELCOP, vol-12,no.2,p.27

Hasan T, Muhaddes T, Camellia S, Selim N, Rashid SF, 2014,Prevalence and experiences of intimate partner violence against women with disabilities in Bangladesh: results of an explanatory sequential mixed-method study, Sage journal, vol. 29 no. 17, page-3105

Hyder,N A, Protecting the Rights of Disabled Persons in Bangladesh, 2015, The Financial Express, 7 March

International Covenant on Civil and Political Rights, 1966

International Covenant on Economic, Social and Cultural Rights (ICESCR)

Justice delayed is Justice denied - A critical overview on Violence against disabled women, Center for the Rehabilitation of the Paralyzed, 2015, Date of Access: 10/01/2016.

$<\mathrm{http}: / / \mathrm{crp}-$

bangladesh.org/index.php?option=com_content\&view=a rticle \&id=240\%3Ajustice-delayed-is-justice-denied-acritical-overview-on-violence-against-disabledwomen $\&$ catid $=37 \% 3$ Anews $\&$ showall $=1>$

Protection of the Rights of the Persons with Disabilities Act, 2013

People with Disabilities (equal opportunities, protection of rights and full participation) Act, 1995

Report on Contextual Analysis of Socio-Economic Situation of Persons with Disabilities in Bangladesh, 2012, Disabled Rehabilitation and Research Association (DRRA)

The Beijing Declaration

The Vienna Declaration and Programme of Action

The Free Dictionary, Disability, Date of Access: $4 / 12 / 2016$,

$<$ http://legal-

dictionary.thefreedictionary.com/Disabled+people>

The Danish Bilharziasis Laboratory for the World Bank, 2004, Disability in Bangladesh: A Situation Analysis, Date of Access; 13/01/2016.

http://siteresources.worldbank.org/DISABILITY/Resour ces/Regions/South\%20Asia/DisabilityinBangladesh.pdf 
Women Watch, n.d., Information and resource on gender equality and empowerment of women, Date of Access; 13/01/2016. http://www.un.org/womenwatch/enable/

Wikipedia, CPRD, The text was adopted by the United Nations general assembly on 13 December 2006 and opened for signature on 30 March 2007. Following ratification by the 20th party, it came into force on 3 May 2008. As of July 2015, it has 159 signatories and 157 parties, including 156 states and the European Union. The Convention is monitored by the Committee on the Rights of Persons with Disabilities,
Date of Access; 13/08/2015.

<https://en.wikipedia.org/wiki/Convention_on_the_Right s_of_Persons_with_Disabilities>

World Health Organization, 2013, Health topics, Disabilities, Date of Access: 3/07/2016.

$<$ http://webcache.googleusercontent.com/search?q=cache :i1_kTe4KWjcJ:www.who.int/topics/disabilities/en/+\&c $\mathrm{d}=1 \& \mathrm{hl}=$ en $\& \mathrm{ct}=\mathrm{clnk} \& \mathrm{gl}=\mathrm{bd}>$ 